7. Reichel E. Results from the TTT4CNV Clinical Trial / E. Reichel, D. C. Musch, B. A. Blodi, M. A. Mainster, TTT4CNV Study Group // Invest. Ophthalmol. Vis. Sci. - 2005. - 46: ARVO E-Abstract: 2311.

8. Newsom R. S. Results 28 months following transpupillary thermotherapy for classic and occult choroidal neovascu- larization in patients with age-related macular degeneration / R. S. Newsom, J. C. McAlister, M. Saeed, K. ElGhonemy, J. D. McHugh // Ophthalmic Surg. Lasers Imaging. - 2005. - Vol. 36(2). - P. 94-102.

Поступила 05.10 .2012

Рецензент к. М. н. Н. Н. Уманец

\title{
RESULTS OF TRANSPUPILLARY THERMOTHERAPY OF SUBRETINAL NEOVASCULAR MEM- BRANES IN PATIENTS WITH WET AGE-RELATED MACULAR DEGENERATION DEPENDING ON CHOROIDAL HEMODYNAMICS
}

Korol A. R., Zadorozhnyy O. S., Dragomiretskaya E. I.

The effectiveness of treatment of patients with wet form of age-related macular degeneration, with the presence of classic type of subretinal neovascularization by the transpupillary thermotherapy statistically significantly associated with the state of the blood supply of the choroid in the macular area according to fluorescein angiography. In patients without circulatory disturbances efficacy reaches $91.7 \%$, with disturbed circulation $-75 \%$. Choroidal ischemic area of more than $10 \mathrm{~mm}^{2}$ is the impediment to improvements in visual acuity in patients with age-related macular degeneration and predominantly classic subfoveal neovascularization treatment by the transpupillary thermotherapy.

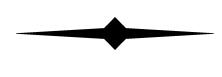

\section{Экспериментальные исследования}

УдК 617.713-089.843-091.8:612.085.1

\section{ГИСТОМОРФОЛОГИЧЕСКОЕ ИССЛЕДОВАНИЕ РОГОВИЦЫ КРОЛИКОВ ПОСЛЕ ПОСЛОЙНОЙ ТРАНСПЛАНТАЦИИ БЕСКЛЕТОЧНОГО МОДУЛЯ СТРОМЫ РОГОВИЦЫ ЧЕЛОВЕКА}

\author{
Н. В. Пасечникова, чл. корр. НАМНУ, д. М. Н., проф., В. В. Вит, д. М. Н., проф., \\ И. О. Насинник, М. Н. С. \\ ГУ «Институт глазных болезней и тканевой терапии им. В. П. Филатова НАМН Украины» \\ Одесса, Украина
}

\begin{abstract}
Експериментальне дослідження виконано на 9 кроликах (18 очей). На обох очах тварин проводилась пошарова трансплантація безклітинного модуля строми рогівки людини по розробленій методиці. У9 кроликів (14 очей) через 2 місяці була відсутня запальна реакція, ознак відторгнення трансплантату не спостерігалось. При цьому відновилась гістоархітектоніка рогівки.
\end{abstract}

Ключевые слова: бесклеточная строма роговицы человека, послойная кератопластика

Ключові слова: безклітинна строма рогівки людини, пошарова кератопластика

Введение. Поражение роговицы вследствие заболеваний, травм и их последствий часто приводит к снижению зрения и слепоте [7]. Более 10 миллионов людей в мире страдают слепотой из-за патологии роговицы [13, 14], но только 120000 ее пересадок выполняется ежегодно [15]. До сих пор наиболее распространенным методом лечения в клинике глазных болезней является пересадка нативной донорской роговой оболочки.

Несмотря на хорошие результаты, отмечаемые после первичной пересадки роговицы (приживае- мость составляет $90 \%$ в течение 5 лет и $82 \%$ в течение 10 лет), результаты при повторных пересадках примерно в два раза хуже (приживаемость составляет $53 \%$ в течение 5 лет и $41 \%$ в течение 10 лет) $[3,12]$.

Существует растущая потребность в материале для трансплантации, что связано с острой нехваткой подходящей донорской ткани во многих странах из-за демографических проблем, увеличения

() Н. В. Пасечникова, В. В. Вит, И. О. Насинник, 2012 
случаев инфекционных заболеваний (ВИЧ, гепатиты, HTLV), более широкого использования рефракционной лазерной хирургии [1]. Наконец, этот дефицит усугубляется несовершенством законодательства и религиозными факторами.

Указанные проблемы, связанные с пересадкой нативной роговицы, а также технические трудности, возникающие при заборе роговичного материала, побуждают к поиску новых путей обеспечения материала для реконструктивных операций на роговой оболочке.

Исследования в области тканевой инженерии роговичных эквивалентов на протяжении последних нескольких лет привели к значительному прогрессу. Так, удалось получить такие эквиваленты с использованием природных или синтетических полимеров, сходных по своим свойствам и толщине с нативной роговицей $[4,6,8,10,11]$.

Альтернативным путем получения материала для кератопластики является удаление клеток и молекул антигенов из тканей роговицы для уменьшения иммунной реакции и получения остова роговицы. В последнее время получение остова на основе нативной ткани стало более привлекательным, поскольку бесклеточный матрикс имеет ту же структуру и состав, что и нативная ткань. Несколько групп исследователей получили бесклеточную строму роговицы с использованием неионных «моющих средств» и ферментов. Они сообщили, что отмытая строма роговицы сохраняет такую же структуру, как и нативная роговица $[5,9$, $16,17]$. Однако «моющие средства», как правило, обладают цитотоксическим эффектом и должны быть тщательно удалены из получаемого объекта. Возможен и другой путь, а именно получение бесклеточной ткани при использовании высокого гидростатического давления, но без «моющих средств» [2].

Однако на сегодняшний день все полученные материалы еще не обладают необходимыми свойствами, предъявляемыми к роговичным имплантам (хорошая биосовместимость, низкая антигенность, высокая оптическая прозрачность, достаточная плотность), чтобы выдержать хирургическую процедуру [4]. В связи с этим целесообразно дальнейшее изучение и разработка новых материалов для кератопластики.

Цель. Изучить гистоморфологические изменения роговицы кролика после послойной трансплантации бесклеточного модуля стромы роговицы человека (БМСРЧ).

МАТЕРИАЛ И МЕТОДЫ. Участки роговой оболочки, полученные из энуклеированых глаз человека, обрабатывались по предложенной нами методике. Согласно ей, они последовательно обрабатывались раствором, включающим Triton X-100 и гидроксид аммония с последующим воздействием ультразвука в растворе декстрана и повторно отмывались в растворе Triton X-100 и гидроксида аммония.
Последним этапом производилось отмывание в фосфатном буфере. Выполняемые процедуры приводили к удалению и вымыванию клеточных элементов роговицы, отщеплению концевых пептидных участков коллагеновых молекул, обусловливающих их антигенные свойства (подана заявка на патент).

Экспериментальное исследование выполнено на 9 кроликах (18 глаз), породы Шиншилла, массой 2,5-3 килограмма. Под общей анестезией с использованием тиопентала натрия 1 г/кг массы в условиях операционной на обоих глазах животных производилась послойная имплантация БМСРЧ. В парацентральной области роговицы трепаном диаметром 4 мм выполнялась насечка. При помощи круглого ножа формировалось ложе. Затем в сформированное ложе укладывался трансплантат БМСРЧ диаметром 4 мм. Фиксация трансплантата производилась при помощи непрерывного шва 10,0. После вмешательства проводилась стандартная противовоспалительная и антимикробная терапия. Животных осматривали 4 раза в неделю, с последующей фоторегистрацией. Офтальмоскопически оценивалось состояние роговицы и трансплантата. Срок наблюдения - два месяца.

Эксперимент проводили с выполнением этических норм, предусмотренных международными принципами Европейской конвенции «О защите позвоночных животных, которые используются для экспериментов и в других научных целях» (Страсбург, 1985) и норм биомедицинской этики, одобренных Первым Национальным конгрессом Украины по биоэтике (2001), а также Закона Украины № 3447-IV «Про захист тварин від жорстокого поводження» (Киев, 2006).

Животных подвергали эвтаназии путем воздушной эмболии в состоянии глубокого наркоза (1мл $10 \%$ раствора тиопентала натрия на 1 кг массы). После забоя животных глаза энуклеировали для проведения гистоморфологических исследований с окраской срезов гематоксилин-эозином. Выполнялась световая микроскопия микропрепаратов.

РЕЗУЛЬТАТЫ. На следующий день после послойной трансплантации на обоих глазах у всех животных наблюдалась смешанная гиперемия конъюнктивы, наличие скудного слизистого отделяемого, трансплантат фиксирован непрерывным швом 10,0. Трансплантаты сохраняли прозрачность, однако отмечалась их незначительная отечность, окружающая ткань собственной роговицы оставалась прозрачной. Реакция зрачков на свет живая (рис. 1).

К 7 суткам отмечалось уменьшение воспалительной реакции, уменьшение отека трансплантатов, частичная эпителизация поверхности трансплантата. На двух глазах отмечалась неоваскуляризация по лимбу.

Спустя 10 суток после операции при осмотре животных на четырех глазах отмечались признаки воспалительной реакции и неоваскуляризация роговицы, отек трансплантатов. На 14 глазах признаков воспалительной реакции не наблюдалось, собственная ткань роговицы и трансплантат сохраняли прозрачность (рис. 2). Наблюдалась полная эпителизация поверхности трансплантата, отмечалось также скопление эпителия вокруг швов. 
На протяжении двух месяцев после трансплантации на 14 глазах признаков воспаления не наблюдалось. Отмечалось просветление трансплантатов (рис. 3). Неоваскуляризация роговицы зарегистрирована на 4 глазах, что сопровождалась помутнением трансплантата.

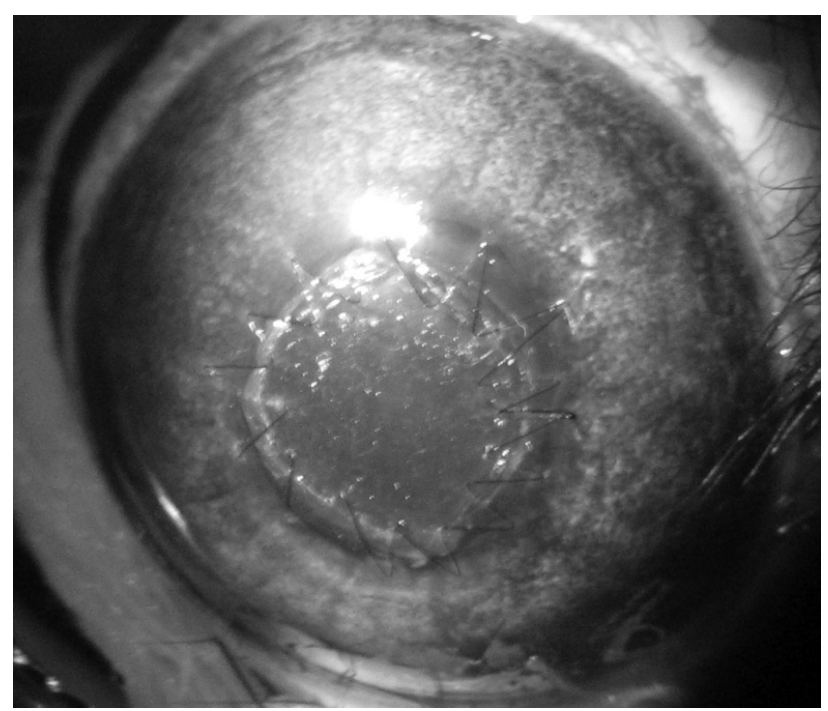

Рис. 1. Роговица кролика на следующий день после послойной трансплантации. Трансплантат и окружающие ткани роговицы прозрачны.

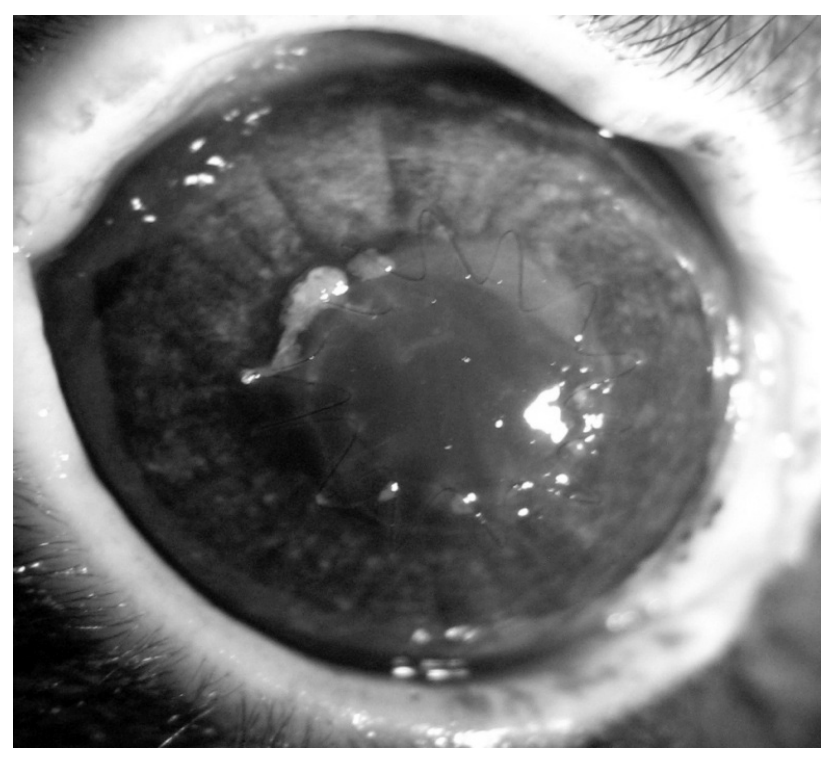

Рис. 2. Роговица кролика на 10 день после операции. Собственная ткань роговицы и трансплантат прозрачны. Полная эпителизация поверхности трансплантата, отмечается скопление эпителия вокруг швов.

При гистологическом исследовании микропрепаратов 14 глаз кроликов через два месяца после послойной пересадки БМСРЧ, роговая оболочка была равномерной толщины практически на всем протяжении за исключением места шовной фиксации. В области шва отмечено утолщение стромальных пластин и их деформация.

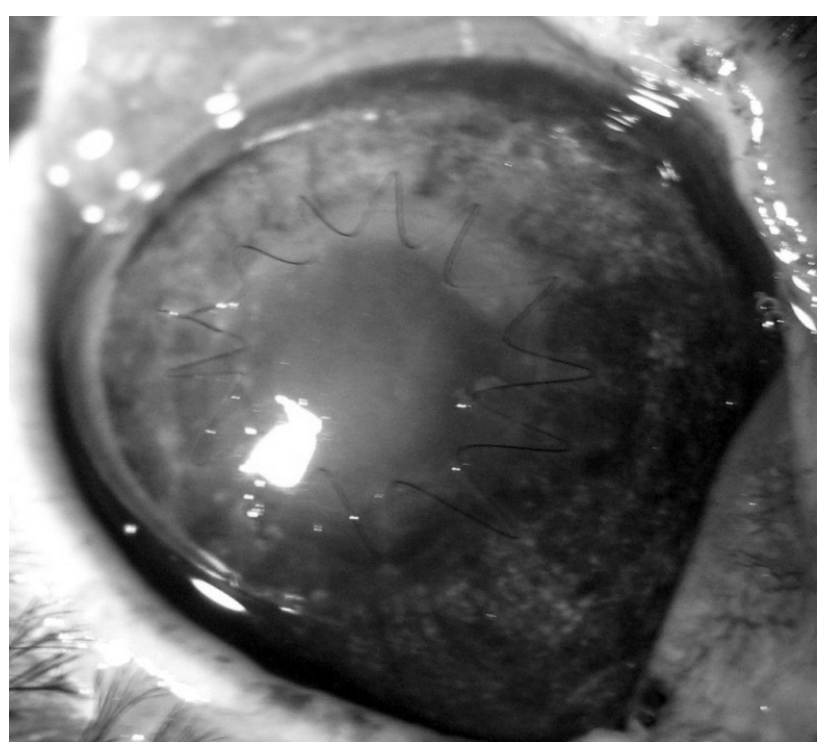

Рис. 3. Роговица кролика через 2 месяца после операции. Собственная ткань роговицы и трансплантат прозрачны.

Между трансплантатом и роговой оболочкой хозяина определяется базофильная полоска, представляющая собой уплотненные коллагеновые стромальные пластины. Признаков воспаления, васкуляризации трансплантата и стромы роговой оболочки хозяина не выявлено. Кератоциты распределены равномерно, по количеству соответствуют норме. Трансплантат покрыт равномерным слоем многослойного плоского эпителия без признаков ороговения. Отличается от эпителия в норме меньшим количеством слоев клеток (4-5) и их уплощенной формой (рис. 4).

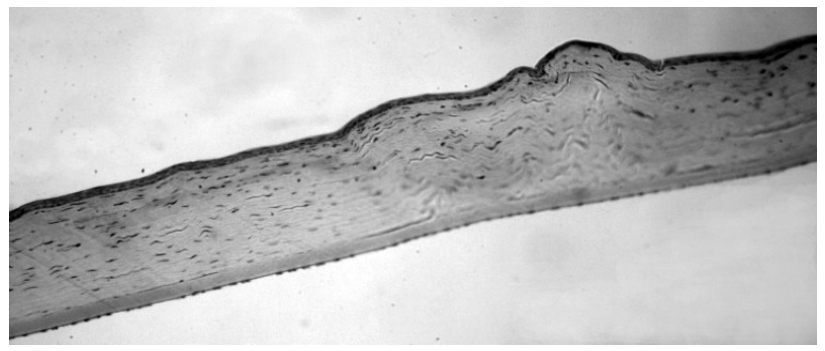

Рис. 4. Гистологический микропрепарат роговицы кролика через 2 месяца после послойной трансплантации БМСРЧ. Приживление трансплантата. Граница между трансплантатом и роговицей хозяина практически отсутствует. Признаков воспаления нет. Отмечается деформация стромальных пластин в месте расположения шовного материла. Гематоксилин-эозин. $\mathbf{x} 70$

В микропрепаратах четырёх глаз кроликов, на которых наблюдалась выраженная воспалительная реакция, через два месяца после послойной пересадки БМСРЧ определяется частичный локальный лизис трансплантата, сопровождающийся инфильтрацией, преимущественно лимфоцитами с незначительным количеством плазматических клеток, трансплантата и лежащей вблизи него стромы ро- 
говицы хозяина. Отмечается прорастание в этой области кровеносных сосудов. Лизирующийся трансплантат покрыт многослойным плоским эпителием, отличающимся нарушением его гистоархитектоники, уменьшением количества клеточных слоев, преобладанием клеток средних слоев и признаками кератинизации. Трансплантат частично сохранен и характеризуется утолщением стромальных коллагеновых слоев, уменьшением количества кератоцитов. При этом отмечается базофильная дегенерация коллагеновых пластин (рис. 5). В некоторых участках трансплантат отсутствует, но сохранившаяся строма роговой оболочки хозяина покрыта многослойным эпителием.

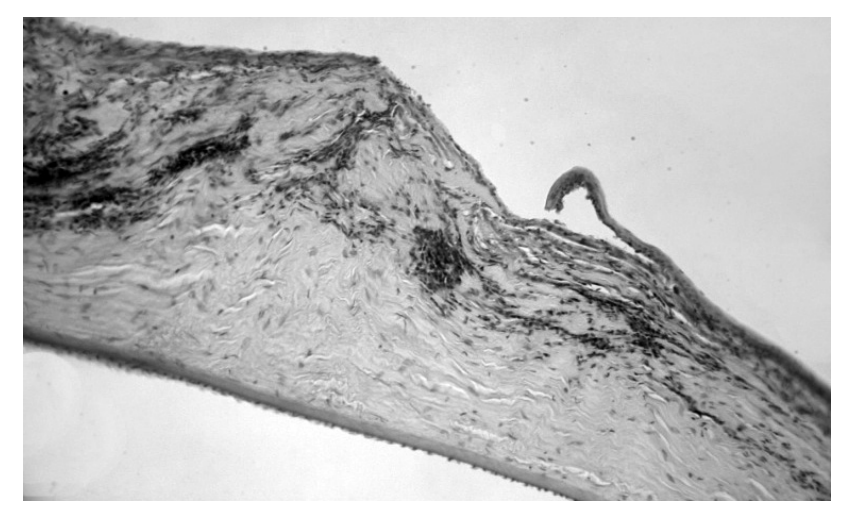

Рис. 5. Гистологический микропрепарат роговицы кролика через 2 месяца после послойной трансплантации БМСРЧ. Утолщение стромы роговой оболочки. Лизис трансплантата на фоне подострого воспаления и васкуляризации. Слущивание переднего эпителия роговицы. Эндотелий сохранен на всем протяжении. Гематоксилинэозин. х 70.

\section{ЗАКЛЮЧЕНИЕ И ОБСУЖДЕНИЕ ПОЛУ- ЧЕННЫХ РЕЗУЛЬТАТОВ.}

Разработанная нами методика обработки роговицы человека дает возможность получить бесклеточную строму роговицы, однако в отличие от иных методик она не требует применения дорогостоящих реактивов и аппаратов, при той же эффективности обработки $[2,5,6,9,16,17]$. После послойной трансплантации в роговицу кролика бесклеточного модуля стромы человека, у 9 кроликов (14 глаз) через 2 месяца отсутствовала воспалительная реакция, признаков отторжения трансплантата не наблюдалось, что свидетельствует о низкой антигенности и совпадает с результатами других исследователей, использовавших в качестве материала бесклеточную строму роговиц свиней $[2,6,9]$ и крупного рогатого скота [5]. Кроме того, эпителизация поверхности трансплантата и миграция клеток роговицы реципиента в трансплантат говорит о способности бесклеточной ткани роговицы к биоинтеграции и истинному приживлению, что также подтверждает ранее полученные результаты применения бесклеточных роговиц in vitro и in vivo [2, 5, 6, 9], однако в нашем случае гистоархитектоника роговицы кролика после пересадки БСМРЧ восстанавливалась полностью.

На основании полученных результатов, свидетельствующих о низкой антигенности и хорошей способности БМСРЧ к биоинтеграции, необходимо проведение клинических исследований для изучения возможности применения бесклеточного модуля стромы роговицы человека в качестве материала для послойной кератопластики в клинике. Это даст возможность получить дополнительный источник материала для кератопластики.

\section{ЛИТЕРАТУРА}

1. Eye Bank Association of America. 1999 EBAA statistical report // Washington, DC. - Eye Bank Association of America, 1999.

2. Hashimoto Y. Preparation and characterization of decellularized cornea using high-hydrostati pressurization for corneal tissue engineering / Y. Hashimoto, S. Funamoto, S. Sasaki [et al] // Biomaterials - 2010. - Vol. 31. P.3941-3948

3. Kaminski S. L. Corneal sensitivity 10 years after epikeratoplasty / S. L. Kaminski, R. Biowski, J. R. Lucas [et al] // J. Refract. Surg. - 2002. - Vol.18. - P.731-736.

4. Liu Y. A simple, cross-linked collagen tissue substitute for corneal implantation / Y. Liu, L. Gan, D. J. Carlsson [et al] // Invest Ophthalmol Vis Sci - 2006. - Vol.47. P.1869-1875.

5. Marquez S. P. Decellularization of bovine cornea for tissue engineering applications / S. P. Marquez, V. S. Martirnez, W. M. Ambrose [et al]// Acta Biomaterialia - 2009. Vol.5. - P.1839-1847.

6. Minami Y. Reconstruction of cornea in three-dimensional collagen gel matrix culture / Y. Minami. H. Sugihara, S. Oono // Invest Ophthalmol Vis Sci. - 1993. Vol.34. - P.2316-2324.

7. Moffatt S. L. Centennial review of corneal transplantation / S. L. Moffatt, V. A. Cartwright, T. H. Stumpf // Clin Exp Ophthalmol - 2005. - Vol.33. - P.642-657.

8. Nishida K. Tissue engineering of the cornea / K. Nishida // Cornea - 2003. - Vol.22. - P.28-34.

9. Pang K. A rabbit anterior cornea replacement derived from acellular porcine cornea matrix, epithelial cells and keratocytes / K. Pang L. Du, X. Wu // Biomaterials - 2010. Vol. 31. - P.7257-7265

10. Reichl S. Human corneal equivalent as cell culture model for in vitro drug permeation studies / S. Reichl, J. Bednarz, C. C. Muller-Goymann // Br J Ophthalmol - 2004. Vol.88. - P.560-565.

11. Schneider Al. Constructing an in vitro cornea from cultures of the three specific corneal cell types / Al. Schneider, K. Maier-Reif, T. Graeve // Vitro Cell Dev BiolAnim. 1999. - Vol.35. - P.515-526.

12. Thompson R. W. Jr. Long-term graft survival alter penetrating keratoplasty / Jr. R. W. Thompson, M. O. Price, P. J. [et al] // Ophthalmology. - 2003. - Vol.110. P.1396-1402.

13. Whitcher J. P. Corneal blindness: a global perspective / J. P. Whitcher, M. Srinivasan, M. P. Upadhyay // Bull World Health Organ. - 2001. - Vol.79. - P.214-221. 
14. Whitcher J. P. Prevention of corneal ulceration in the developing world / J. P. Whitcher, M. Srinivasan, M. P. Upadhyay // Int Ophthalmol Clin. - 2002. - Vol.42. - P.7177.

15. World Health Organization. Report of consultation meeting on transplantation with national health authorities in the western pacific region. -2005 . - P.1-63.

16. Wu Z. The use of phospholipase A2 to prepare acellular porcine corneal stroma as a tissue engineering scaffold /
Z. Wu,Y. Zhou, N. Li [et al] // Biomaterials. - 2009. Vol.30. - P.3513-3522.

17. Xu Y. G. Development of a rabbit corneal equivalent using an acellular corneal matrix of a porcine substrate / Y. G. Xu, Y. S. Xu, C. Huang [et al] // Mol Vis. - 2008. Vol.14. - P.2180-2189.

Поступила 23.07.2012

Рецензент проф., Д. М. Н. Э. В. Мальцев

\title{
HISTOMORPHOLOGICAL STUDY OF THE RABBIT CORNEA AFTER THE LAMELLAR TRANSPLAN-
} TATION OF HUMAN ACELLULAR CORNEAL STROMA

\author{
Pasechnikova N. V., Vit V. V., Nasinnik I. O. \\ Odessa, Ukraine
}

The experimental study was performed on 9 rabbits (18 eyes). A lamellar keratoplasty of the human acellular corneal stroma module was performed in both eyes. There was no inflammatory reaction in 9 rabbits (14 eyes), no signs of graft rejection were observed 2 months later. At the same time corneal histoarchitectonics was repaired.

\section{СТРУКТУРНЫЕ ИЗМЕНЕНИЯ СОСУДОВ МЕДУЛЛЯРНОЙ ЛУЧИСТОСТИ СЕТЧАТКИ И ХОРИОРЕТИНАЛЬНОГО КОМПЛЕКСА КРОЛИКА ПОД ВОЗДЕЙСТВИЕМ ВЫСОКОЧАСТОТНОЙ ЭЛЕКТРОСВАРКИ БИОЛОГИЧЕСКИХ ТКАНЕЙ ПРИ МОДЕЛИРОВАНИИ ВНУТРИГЛАЗНОГО КРОВОТЕЧЕНИЯ}

\author{
Н. В. Пасечникова, д. мед. Н., В. В. Вит, д. мед. н., \\ В. А. Науменко, д. мед. Н., Н. Н. Уманец, к. мед. н.
}

ГУ «Институт глазных болезней и тканевой терапии им. В. П. Филатова НАМН Украины»

\begin{abstract}
На моделі внутрішньоочної кровотечі у кроликів встановлено, що використання високочастотного електрозварювання біологічних тканин (модифікований генератор EK-300M1) параметрами електричного струму: напруга - 18-20 В, сила струму до 0,1 A, експозиція 1-2 c, частота $66 \kappa Г и$, викликає коагуляцію судин сітківки та облітерацію їх просвіту з явищами коагуляційного некрозу сітчастої оболонки в області діï, при цьому його ступінь значно менше ніж при діатермокоагуляції параметрами електричного струму: потужність - 10 Bm, частота 365 кГи, експозиція 1-2 секунди.
\end{abstract}

Ключевые слова: модель внутриглазного кровотечения, сосуды сетчатой оболочки, высокочастотная электросварка биологических тканей, диатермокоагуляция

Ключові слова: модель внутрішньоочної кровотечі, судини сітчастої оболонки, високочастотне електрозварювання біологічних тканин, діатермокоагуляція

Введение. Интраоперационное кровотечение считается одним из основных осложнений задней закрытой витрэктомии у больных пролиферативной диабетической ретинопатией, внутриглазными новообразованиями (ангиоматоз ГиппеляЛиндау, меланома сосудистой оболочки), которое снижает эффективность хирургии, в ряде случаев может быть неконтролируемым и приводить к тяжелым последствиям [1-4]. Кроме того, интраоперационное кровотечение во время витрэктомии увеличивает риск развития гемофтальмов в раннем послеоперационном периоде, что подчеркивает необходимость тщательного интраоперационного гемостаза [5]. Общепринятым методом остановки интраоперационного внутриглазного кровотечения остается диатермокоагуляция биполярным эндовитреальным зондом [6].

Метод высокочастотной электросварки биологических тканей применяется в клинической практике в общей хирургии с 1996 года для купирования и профилактики интраоперационных кровоизлияний и, как показали экспериментальные и клинические исследования, по сравнению с диа-

(C) Н. В. Пасечникова, В. В. Вит, В. А. Науменко, Н. Н. Уманец, 2012 